\title{
DIE INVLOED VAN CALVYN OP DIE GELDENDE KERKORDES IN SUID-AFRIKA 1652-1983
}

B. Spoelstra

\section{INLEIDING}

Dit is ' $n$ onbegonne taak om Calvyn se invloed op elke bepaalde Kerkorde en Kerkwet wat in SA gegeld het en nog geld in een artikel na te gaan. Daarenteen kan sy invloed in die Nederlandse kerkordelike ontwikkeling van 1571 tot en met die Dordtse KO van 1619 maklik uitgewys word omdat dele van die KO reeds in 1571 regstreeks aan die Institusie ontleen is.

\section{KERKORDE TYDENS DIE VOC-BEWIND 1652-1795}

2.1. Het ' $n$ offisiële kerkorde aan die Kaap voor 1804 gegeld?

Calvyn word die "vader van die Gereformeerde Kerkreg" (Kleynhans 1982:11) genoem omdat hy deur sy Institusie, Kategismus, Confessio Gallicana en die voortvloeiende Confessio Beligica van $\mathrm{De}$ Bres 1561, Kommentare, adviese, traktate groot invloed uitgeoefen het op Nederland. Daarvandaan het verskillende rigtingsinvloede tot in die 20ste eeu na Suid-Afrika deurgewerk. J. D. Vorster (1956 : 83-85) beweer dat die Kerkorde van die Dordtse Sinode 1619 formeel aan die Kaap gegeld het ( $p p$ 83-85). J. P. Jooste (1946:58) sê versigtiger dat dit 'n "onoffisiële rigsnoer" vir die kerklike lewe aan die Kaap was.

Die stelling dat ' $n$ bepaalde Kerkorde en by name die Dordtse Kerkorde van 1619 voor 1804 formeel aan die Kaap gegeld het is foutief. Dit gaan waarskynlik uit van die 18de eeuse verenigingsreg (en Engelse kerkreg, vgl. Pienaar: In die Skriflig 1984). Daarvolgens moet die kerk as genootskap deur 'n kerkorde gekonstitueer word. Retrospeksie deur hierdie bril mag die vraag wek na watter kerkorde gegeld het.

Die verwysing na of beroep op die Dordtse Kerkorde vir gesag of die praktiese toepassing van duidelike beginsels wat in die Dordtse Kerkorde voorkom, bewys nog nie dat dié Kerkorde formeel as Kerkorde gegeld het nie. Indien die DKO die geldende KO was, moes 'n bevoegde instansie die DKO aangekondig of in werking gestel het. In orde van moontlikheid beteken dit dat of die Klassis Amsterdam, of die Here XVII of die Politieke Raad die DKO, of dele daarvan vir die kerke moes geproklameer het. So 'n bewys ontbreek geheel en al. Dit is onaanneemlik om te aanvaar dat een of meer kerkrade voor 1804 oor die bevoegdheid beskik het om 'n KO in werking te stel.

Daar is aan die ander kant sterk getuienis dat nie die DKO nie en geen ander KO formeel aan die Kaap voor 1804 kon gegeld het. 'n Mens kan slegs aanstip: Die Provinsie Noord-Holland waarbinne die Klassis Amsterdam en Here XVII gesetel was, het nie die DKO onderhou nie. Die Here XVII het nie kerklike patrone gedikteer nie, maar juis die Klassis Amsterdam daarby gehaal. Indien 'n Kerkorde in werking was, moes die Kaapse Kerke voor 1746 of daarna 
op sterkte van die Kerkorde in klassis kon saamkom. Die Franse (1559) en Nederlandse Kerkordes (1571) het juis met die oog op koöperasie van die kerke in kerkvergaderings tot stand gekom en nie om die plaaslike kerke voor te skryf nie. Die plaaslike kerke het immers oral lank voor kerkordes daargestel was, bestaan en opgetree. In Genéve was die KO in 1542 en 1561 skynbaar slegs vir een plaaslike kerk bedoel - maar die geskiedenis leer weer dat dit daar juis die verhouding tot die politieke owerhede moes reël.

Omdat aan die Kaap voor 1804 geen Kerkorde offisieëel en formeel gegeld het nie, kan geen invloed van Calvyn op so 'n Kerkorde aangedui word nie. Dit beteken egter hoegenaamd nie dat Calvyn geen invloed gehad het op die orde wat in die losstaande plaaslike kerke nageleef is nie. Die kerke was immers grootliks selfstandig, behoudens die saambinding onder die Politieke Raad en losse verband eerstens onder die kerk van Kaapstad en tweedens onder voogdy van die klassis Amsterdam. Op sigself dra hierdie posisie ook geen stempel van Calvyn nie. Inteendeel is die owerheids- en klassis patronaatskap oor die kerke aan Calvyn se denke vreemd.

Gedurende Lutherse en Calvynse reformasie het kerke (gemeentes) op plekke rondom die prediking en sakramentbediening ontstaan. Dit was meer dikwels slegs moontlik deur die aktiewe steun van owerhede wat hulle nasionale state van die ou Middeleeuse kerklike en politieke imperiums wou vrymaak. Kerkordes is juis ontwerp om die verhouding tot die owerhede (Genéve 1537, 1542) of tussen die kerke onderling (Frankryk 1559, Nederland 1571) te reël. Dit is juis die ontstentenis aan so 'n reëling wat De Mist sy hand in 1804 aan 'n Kerkorde laat sit.

Laastens, indien die owerhede in Nederland juis geweier het om die DKO in 1619 te aanvaar - waarom sou hulle dieselfde Kerkorde formeel en offisiëel vir die verversingspos aan die Kaap voorskryf?

'n Mens kom dus tot die slotsom dat die Kaapse kerke (gemeentes) plaaslik die notae ecclesiae voldoende geag het. Die kerk (gemeente) is bepaal deur die eenheid van geloof, die gemeenskap deur die bediening van die genademiddelle en die handhawing van die kerklike dissipline. Die bestaan van "een Kaapse kerk" of van een "Hervormde" of "Gereformeerde" kerkgenootskap, was aan die Kaapse kerke voor 1804 totaal vreemd. Die reformatoriese vertrekpunt vir kerkwees was gemeenskap rondom bediening van die genademiddelle.

\subsection{Die kerkordelike situasie 1652-1804}

2.2.1 Kragtens die Oktrooi van die State Generaal het die VOC onder beheer van die Here XVII ook die ius patronatus in sacra uitgeoefen. In hlerdie opsig was die basis meer aan Luther en Zwingli as aan Calvyn ontleen. Tegelykertyd het die Kaap as verversingstasie vir die VOC nie die ekonomiese waarde van Batavië gehad nie. Die Kaap is maar met die oog op Batavië onderhou. Die Kaapse kerke is dus as't ware as onderhorig aan Nederland en Batavië beskou. 
Bediening was vir die mense nodig - maar 'n selfstandige kerklike ontwikkeling is tot 1804 nie voorsien nie.

2.2.2 Die State Generaal het die Dordtse Kerkorde van 1619 nie goedgekeur nie. Die State (Provinsies) het egter provinsiale kerkordes daargestel wat uit die aard van die saak min of meer op die gemeenskaplike Nederlandse kerkregtelike tradisie geskoei was, wat ook in die DKO van 1619 beliggaam was. Tot 1816 het nooit weer 'n Nasionale Sinode in Nederland vergader nie. Die situasie pas aan by die tipies Nederlandse voorliefde vir plaaslike vryheid en verantwoordelikheid en gevolglik vir desentralisasie wat die plaaslike kerk beklemtoon (Spoelstra 1980: 5v). Dit staan in skril kontras met Engelse en Skotspresbiteriale voorliefde vir gesentraliseerde organisasiepatrone (vgl Wypkema 1945: 148; Spoelstra 1963:34-45). Kerkordes reël sedert die $18 \mathrm{de}$ eeu by uitstek kerklike sentralisasie.

2.2.3 Die Klassis Amsterdam binne die provinsie Noord-Holland het die VOC kerklik gelei. Die situasie 1652-1804 weerspieël die tipiese kolonialistiese opset waarin kerke in 'n kolonie nie dieselfde status en regte as hulle eweknieë in die Vaderland geniet nie. Die "ONS" in die Vaderland was voogde vir die "HULLE" in die kolonies. "Vaderlanders" verkeer immers "tydelik" in die kolonie totdat hulle terugkeer "huistoe". Die posisie van die Kaapse kerke kan tot 1795 grootliks met die kerkregtelike posisie van die bemanning op 'n VOC-skip vergelyk word. Dieselfde skakeling tussen die VOC en Klassis Amsterdam oor predikante en sieketroosters vir skepe het met die oog op die Kaapse kerke plaasgevind.

Die regtelike basis van ' $n$ corpus christianum en ius patronatus in sacra is van Romeinse en Germaanse oorsprong. Die aanwesigheid van ' $n$ Kommissaris-politiek in die kerkrade bots met Calvyn se opvatting van geestelike kerkregering. Calvyn het juis skerp onderskei tussen regimen spiritualis en regimen naturalis (Vgl Spoelstra $1982: 235-237$ ).

Kleynhans meen dat Calvyn as kind van sy tyd aan die staat in sommige opsigte te veel seggenskap gegee het $(1982: 12)$. Ek meen dat Calvyn in die Ordonnances Ecclesiastiques 1541 en 1561 'n kompromis moes aangaan om as kerk binne die Geneefse corpus christianum met sy ius patronatus in sacra te oorlewe. Calvyn verwag slegs dat die owerheid die kerk sal "beskerm" en selfstandige kerklike ontwikkeling sal waarborg (Inst IV $20 \mathrm{ii}$, viii). Hy ken aan die owerheid geen ius in sacra toe nie, want God het vir die godsdiens ' $n$ ander regering daargestel (VI, 20 i).

2.2.4 Die Klassis Amsterdam het direk en indirek (deur die VOC) voogdyskap oor die Kaapse kerke uitgeoefen. Die Kaapse kerke het nie die Klassis konstitueer nie, en tog het die kerke in Amsterdam hulle wil op die Kaapse kerke afgedwing. byvoorbeeld toe die kortstondige Gekombineerde Vergadering (1745-1759) beeindig is. Hierdie situasie bots vierkantig met Calvyn se ywer teen kerklike heerssug en heerskappyvoering. So wyd het sy weersin teen hierargie verbrei dat die Nederlandse kerke te Emden in 1571 as uitgangspunt vir kerkorde poneer: "Geen kerk zal over een andere 
kerk, geen dienaar des Woords, geen ouderling, noch diaken, zal de een over de ander heerschappij voeren, maar een iegelijk zal zich voor alle suspiciën, en aanlokking om te heerschappen wachten" (A. D. Pont 1981: 103, Emden art 1; 186, DKO art 84).

Wanneer die Gekombineerde Vergadering in 1759 afgeskaf word, skryf Kaapstad aan die Klassis dat "yder onser kerke, ofte op zichzelven ofte door middel van onse Caapsche kerke - welke laatste voor die oprigtinge der Gekombineerde Kerkvergaderinge plaats heefte gehad - met UWE voortaan sullen moeten correspondeeren" (Spoelstra 1906:290). Hierdie heersende posisie van enn kerk oor ander kerke bots vierkantig met bogenoemde beginsel. Die skrikwekkende heerskappyvoering oor die Kaapse kerke blyk verder uit die feit dat Klassis Amsterdam die Gekombineerde Vergadering in 1759 kon afskaf omdat die kerke met Partikuliere Suid-Holland korrespondensie gesoek het.

2.2.5 Die afsonderlike Kaapse kerke (gemeentes) was voor 1804 nooit kerkordelik in moderne taal 'n "Kaapse Kerk" nic. Dic Franse (1559) en Nederlandse kerke (1571) kom as kerke wat dieselfde geloof bely met mekaar in Kerkorde ooreen om mekaar terwille van die geloofseenheid in kerkregering by te staan. Indien 'n Kerkorde aan die Kaap gegeld het, sou die Gekombineerde Vergadering daaruit gevolg het. Die feit dat die Gekombineerde Vergadering egter ad hoc toegestaan en beëindig is, onderstreep dat die kerke aan die Kaap eers in 1804 wanneer De Mist die verhouding tussen owerheid, Gereformeerde en Lutherse Kerke reël 'n Kerkorde ontvang.

\subsection{Calvynse invloed in die kerklike praxis}

Indien in lyn met die bedieningsentriese kerkbegrip van die Reformasie na die plaaslike kerke aan die Kaap voor 1804 gekyk vord, blyk dat die orde, die eintlike kerkwees, kerkdiens, kerk-seremonies, kerk-leer en kerk-regering primêr bepaal is deur die Belydenis (vgl bv. art 27-32 NGb) en natuurlik die toepassing van Nederlandse patrone waarin Calvyn wel groot invloed gehad het.

Die NGb bely die een kerk van God (art 27) wat op 'n bepaalde plek konkreet sigbaar aanwesig word (art 28) waar die kenmerke van die kerk voorkom (art 29) onder toesig van presbiter-opsieners (art 31), predikante en diakens in kerkraad (art 30). Christus is egter Hoof van sy kerk en daarom het dienaars net beperkte mag om voor te skryf. Die dienaars se taak is om eendrag en eenheid (van die leer) gehoorsaamheid aan God te bevorder wat die ban nodig maak (vgl Inst IV 10 xxxii en art $32 \mathrm{NGb}$ ). Dit bepaal eintlik die orde in die Kaapse Kerke tot 1804.

Belydenis van dieselfde geloof is die wese van die kerk as gemeenskap in Christus. Die kerke duld geen leerafwyking by sendeling George Schmidt (1742). sieketroosters L. van Dyk (1843) en W. Raedsel (1745) of ds. H. H. van der Veen (1757) en onderwyser N. N. de Beer (1769) nie. Om dieselfde rede staan hulle die Lutherane teen (Spoelstra $1963: 2 \mathrm{v}$ ).

Calvyn sê daar is net een kerk van God (Inst IV I) wat op 
aarde sigbaar word waar die Woord suiwer gepreek en gehoorsaam en die sakramente na waarheid bedien en ontvang word (Inst IV 1 ix-xii) en die sleutels (IV 1 xxii) of tug volgens die Woord van God (IV 7 xxiii) toegepas word. Dit verbaas dus nie dat die toepassing van kerklike tug in Genéve (Vgl Plomp, 1969: 218-232) feitlik netso voorkom in die Kaapse sensura morum tot diep in die agtiende een en by die kerke in die GKSA familie tot in die middel van die 20ste eeu. Die tugoefening is nie deur 'n formele Kerkorde bepaal nie.

Die Calvynse opvatting dat die gemeente kerk is, het bygedra tot die afskeiding binne so baie N. G. gemeentes in die vorige eeu (vgl Van der Watt 1979). Die Trekkende Gemeente na Port Natal twyfel ten spyte van sensuur van die Kaapse Sinode van 1837 nie daaraan dat hulle kerk is nie. Die Gereformeerdes stel by Rustenburg 1859 of Reddersburg 1859 nie 'n "kerkvraag" om 'n ander "kerk" met 'n ander "naam" as 'n NG of NH te stig nie. Hulle vra nie na die "kerk" van Postma in Nederland nie. Tog was hulle doodseker dat hulle "kerk" is omdat kerk vir hulle deur die godsdiens wat hulle in die gemeente beoefen, bepaal word. Kerk is waar hulle die Woord, Sakramente en kerkregering plaaslik ervaar soos hulle dit met hulle verstaan van die Skrif kon rym (vgl notae ecclessiae by Calvyn).

Calvyn ag 'n Sinode nodig om leer vas te stel (Institusie IV, 9). Hy gee aan die kerkraad $(I V, 11)$ egter die groot taak om die kerk in orde te hou. Die kerkraad bestaan slegs uit die opsieners, dws ouderlinge en predikante. Die DKO (art 38) het die diakens in klein kerkrade as hulp-ouderlinge bygebring. Aan die Kaap is die Calvynse ampdiffirensiasie tussen ouderlinge en diakens (Inst IV 3, viii; DKO artt 23,25$)$ vasgehou, maar die kerkrade aan die Kaap is "klein" gehou en die diakens konsekwent by die kerkraad gereken.

Die diensdiffirensiasie tussen predikant, ouderling en diaken is tipies Calvyns (vgl Inst IV 3 vii-xvi, 12 ii ev). Algemene bestuurspligte het voor 1804 by die VOC berus.

\section{DIE KERKORDE VAN DE MIST 1804}

De Mist het 'n Kerkorde op 21 Augustus 1804 geprokJameer omdat aan die Kaap geen Kerkorde formeel gegeld het nie. Kaanstad het versoek dat die Gekombineerde Kerkvergadering heringestel word en die verhouding tot die Lutherane wat die VOC pas erken het, was on luidelik. Die reëling hiervan baar juis die eerste officiële Kerkorde aan die Kaap. Daarom reël die eerste aloemane afdeling die interkerklike situasie en die tweede hantel met die "Hervormde" kerke wat volgens De Mist nou in een oorkoepelende "Kerkgenoodschap" verkeer.

In De Mist se Kerkorde het Calvyn hoogstens op formele terminologie soos kerk, kerkraad, ouderlinge en diakens invloed gehad. De Mist gee aan die begrippe totaal ander inhoud as Calvyn. Dit lei tot die gevolgtrekking dat Calvyn geen invloed op die eerste formele Kerkorde in Suid-Afrika 1804 uitgeoefen het nie. 


\section{DIE KONTRAS TUSSEN CALVYN EN DE MIST}

\subsection{Twee verskillende gesagspole:}

Die Rennaissance aktiveer in Wes-Europa die Griekse filosofiese apriorië nl natuur en mens. Naturalisme en humanisme beïnvloed ook die Westerse kerklike ontwikkeling. Die Reformasie is in 'n sekere sin aan die humanisme van die 16de eeu verwant (vgl Spoelstra 1975: 37v). Die Reformasie breek egter met die Roomse sowel as die humanistiese gesagsbegrip. (Van der Linde 1965: $9 \mathrm{ev}$ ). Skrifgesag word teenoor priestergesag en outonomie van die individu gestel.

Calvyn gaan van die soewereiniteit van God en die koningskap van Christus in kerk en godsdiens uit (Van der Walt 1976:122v). De Mist opereer egter met die 18de eeuse outonomie as natuurreg van die redelike mens. Elke individu het van die natuur die reg verkry om vrye keuses uit te oefen. Die belange van die Burgerstaat gaan bo almal uit (vgl De Mist 1804) maar daarbinne kan individue vrywillig kontraktueel bv. 'n kerkgenootskap oprig, in welke geval die wil van die meerderheid die hoogste gesag dra (Kleynhans 1982: 86). Die gesag van God en die Skrif is volledig uitgesluit. Die vraag of die kerke aan die Kaap dit vrywillig of teensinnig aanvaar het (vgl. apologie Kleynhans 1974: 55) is $\mathrm{m}$ i irrelevant. Dit was die feitlike situasie.

"Die grondslae en geestesmerk van die liberale beweging is nie te vinde in sy strewe na vryheid nie, maar in sy verwerping van gesag" buite die mens (Hanekom 1951: x, 29). De Mist se Kerkorde van 25 Julie $1804 \mathrm{kom}$ in dele woordeliks met die Dekreet van die Nasionale Vergadering van 5 Augustus 1796 in Nederland waarvan De Mist lid was, ooreen. (Hanekom $1951: 118$ ).

Calvyn sê dat God alleen wette in die Skrif vir sy kerk gee (Inst IV 1 ix; 3 i; 8 iv, viii; 9 ii, viii, veral 10 vi, vii ens). De Mist sê daarteenoor dat bevoegde mense as owerhede alle kerklike sake, insluitende die Geloofsbelydenis, moet reël en vasstel. De Mist dien sy Kerkorde aan op die "consideratiën van Gouverneur en Raden van Politie" (Jooste 1946 : 90).

Hier tref ons 'n tipiese anomalie van die Liberalisme aan. In teorie vertrek dit van die vrye wil van die individu en genootskap. In praktyk dikteer die "staat" (in werklikheid 'n paar owerheidspersone) en toring uit bo elke genootskap. Die kerke oor wie dit gaan, is selfs by die opstel van die Kerkorde nie geken nie.

Calvyn het dus geen invloed in die mees fundamentele beginsel van die Kerkorde van 1804 gehad nie.

4.2 Verskillende kerkregeringspole:

By Calvyn staan die dienste ("ampte") of liewer die bediening wat Christus die Hoof gebruik, voorop. Eintlik roep en gee $\mathrm{Hy}$ ' $n$ bepaalde persoon (as 'n gawe) met 'n bepaalde opdrag (diens) aan die wêreld (Rom. 10) en sy kerk.

Die bediening gaan aan die kerk vooraf en kom nie uit die kerk op nie. Die kerk is die vrug van die bediening van dle genademiddele (Inst IV $1 \mathrm{x}$ ). Volgens Calvyn het God mense tot die ewige 
lewe uitverkies in die eenheid van ware geloof in Christus (IV 1 iiiii). God maak salig deur die prediking van die Evangelie (IV $1 \mathrm{v}$ ). Daarvoor gebruik Christus instrumente (dienste) om die Woord (Inst IV, 3, NGb 30-32) te bedien waardeur die Gees geloof werk en so vergader, beskerm, en bou Hy sy kerk (Heid Kat S 21).

Die 16de eeuse Kerkordes handel daarom oor die dienste voordat van kerkvergaderings gepraat word. Die dienste het geen locus standi in hulself of in die kerk nie. Trouens vir Calvyn is die daarwees van die opsiener-diens (soos by Rome) ook goddelik gegewe gawe (Ef $4: 11,1$ Kor. 12 .28) en bepaal dit kerkinstituering. So handhaaf hy ' $n$ instrinsieke en selfs mistieke eenheid tussen die een onsigbare universele liggaam van Christus en wat daarvan rondom die bediening van genademiddelle in die gemeente van gelowiges sig-

baar word.

De Mist se Kerkorde neem nie Christus en sy dienaars nie maar die kerk as menslike fenomeen as uitgangspunt. Hy laat die mistieke wortels van die onsigbare universele kerk totaal los (soos Luther ook sigbare kerk van ander orde gereken het). Die kerk is net sigbare organisasie wat oorkoepelend as "kerkgenootskap" gekonsepeer word. "Kerk" word 'n idee, 'n abstraksie van die denke, wat die korporatiewe en kontraktuele eenheid van die "lidmate" in wil, voorneme en oortuiging veronderstel. Die kerk word as ' $n$ objektiewe grootheid, op sigself beskou, 'n regspersoon, waarby 'n mens kan aansluit of jou van kan onttrek. Die kerk as wil van die totaalsom lidmate word in elke gemeente sigbaar. Die genootskap skryf gevolglik die funksies van sy besture en ampte voor. "Amp" kry die betekenis van ampienaar van 'n instelling, posisie of waardigheid in 'n organisasie. Hierdie eklesiologie verplaas daarom die Calvynse ministeriële, bedieningsentriese of diakonologiese kerkbegrip wat alle aksent op die kwaliteit van geloof, godsdiens en lewe in die gemeente gelê het en die kerk word sekulêre, sigbare grootheid.

Opmerking: Rome, Calvyn episkopaalse en biskoplike kerkregeringstelsels het in lyn met die Skrif-tradisie volgehou dat Christus Hom van opsieners (biskoppe) bedien. Dit is opmerklik dat juis hierdie tradisie in ons tyd nog die meeste probleme ondervind om vroue in die opsieneramp toe te laat. Daarteenoor het stelsels wat sedert die Rasionalisme van kerk as vertrekpunt neem, geen moeite om moderne wense te akkommodeer nie. Volgens hulle kan "die kerk" self sy ampte omlyn en so aan die feminisme toegee en diskriminasie teen die vrou ophef. Dit is inderdaad beslissend of daar van Christologiese (ministeriële) of ekklessiologiese (institusionele) apriorie in die kerkregering uitgegaan word.

Kerkregering is vir Calvyn bediening van die gesag van die Woord. De Mist beskou dit "bestuur" van 'n genootskap (vgl ook art 1, Reglement Sinode 1824). Die daar-wees en opdrag aan die kerklike dienaars ontleen Calvyn aan die Skrif en word gevolglik bely (NGb 30, 31). Die bevestigingsformuliere motiveer hierdie opvatting verder.

Alhoewel die Dordtse KO ook kortliks die dienste van predikante (art 16), professore (art 18), ouderlinge (art 23) en diakens (art 
25) omskryf, het die KO's nooit bedoel dat die Kerkorde ampte bepaal en ampsbevoegdheid verleen nie.

Prof. J. J. de Klerk (Kleynhans 1974: 113) merk met reg op dat by De Mist die ampsbegrip verander. Die amp ontleen sy funksie en gesag aan die Reglement. Kleynhans (1974: Die kerkregtelike ontwikkeling van die NG Kerk in SA 1795-1962, 53) verwys na Reglement 1824: "Art 20 maak voorsiening vir die bestaan van 'n kerkraad in elke gemeente. Daar is ook sprake van 'n reglement oor kerkraadslede...". By implikasie gaan die Reglement aan die kerkraad vooraf.

Volgens hierdie opvatting moet daar eers 'n kerk wees wat in sinode saamkom om daar die ampte te omlyn. Hierdie kerksentriese eklesiologiese (kollegialistiese) opvatting staan lynreg teenoor Calvyn se Christologiese en bedieningsentriese (ministeriële) kerkordebegrip. Hoewel talle huidige kerkregeringstelsels formeel Christus as Hoof erken, opereer hulle onder gesag van die "kerk" en beroep hulle daarop dat Christus aan die kerk die mag gegee het om te regeer en te bepaal. Die vraag is dan nie meer wat sê Christus nie, maar wat sê die kerkbesture, wat het die sinode bepaal. 4.3 Verskillende verstaan van kerk:

Vir Calvyn het Christus per definisie net éen liggaam, net één kerk (Inst IV 1 ii), ongeag die feit dat ons sê dat daar baie kerke is. Hierdie gelowiges in Christus kom konkreet op aarde saam waar die Woord bedien word (Inst IV $1 \mathrm{v}$ ). Die baie gemeentes waar die genademiddelle en sleutels van die hemelryk, die merktekens van die ware kerk suiwer bedien en ontvang word, vergestalt die één kerk sigbaar (Inst IV 1 vii-xii, xxii; $21 ; 31 ; 9$ i, iv). Calvyn (en (Luther) stig nie ander "kerke" (strukture of organisasiepatrone) teenoor Rome nie, maar hervorm die kerklike bedieninge ooreenlkomstig die sola Scripture-norm. Calvyn verdoem die "pousdom", die valse bediening, maar weet dat onder die pousdom nog kerke van God is (Inst IV 2 xxii). Die gelowiges, mense, is die één katolieke kerk van God. Die kerk is nooit struktuur of organisasie wat opjektief bestaan nie. Daarom maak menslike organisasie (bv in 'n sinode of kerkverband) nie 'n kerk (as struktuur) in Bybelse sin nie.

Calvyn onderskei die kerk nie soos Kuyper in "instituut" en "organisme nie. Kuyper (en De Mist) identifiseer instituut met kerk. Daarteenoor is die kerk vir Calvyn nie "offentlichrechtliches Genossenschaft" of "Körperschaft im enger Sinne" nie (Bohatec 1961: 377-379). Kerk is organiese gemeenskap (organisme) wat deur die kenmerke van die kerk geteken word (Inst IV 3 i, ha Ef $4: 4 v$ ). Die één kerk van God word die duidelikste aan die nagmaal sigbaar (Bohatec 1961: 276, 280). B. C. Milner sê van Calvyn se kerkbegrip: "God has ordained both the preaching of the Word and the administration of the sacraments, and when coupled with the efficacious working of the Holy Spirit they constitute the order which marks the reality of the church ... According to Calvin, then we cannot think of the church as a legally defined institution... Rather the church must be defined dialectically as union with Christ in, through and together with the means by which the Spirit 
brings us to Him" (Milner 1970: $123 \mathrm{v}$; Vgl Spoelstra 1982: 238241).

De Mist is Rasionalis wat volgens die filosofie van Rousseau die kerk as "1 Cantrat social" verstaan. Outonome individue onderhandel, verenig vrywillig en delegeer hulle gesag deur middel van verteenwoordigers na die hoofbestuur van die genootskap. Die gemeente word beskou as "societas aequalis et libera" waarin die amp ecclesia mandatarius is (Van der Walt 1976: 106: Van der Linde 1965: $78 \mathrm{v}$ ). Die Kerkorde of kerkwet is in wese die afspraak of konstitusie wat die kerk as eenheid bepaal.

De Mist (en die kollegialisme) mag invloed van Luther se cuius regio eius religio of Lutherse indiffirentisme oor die sigbare kerkorganisasie ondergaan het. Die Lutherse twee-ryke leer het vir baie regsgeleerdes en politici by hulle rasionalististiese Deïsme aangesluit.

De Mist aanvaar dat die "beschaafde Maatschappij" nie sonder godsdiens deug en goeie sedes kan bestaan nie. (Aanhef van sy Provisionele Kerkorde 1804). Gevolglik vorm beskaafde mense verenigings of genootskappe (kerke) en hy neem die genootskanpe as vertrekpunt: "Alle Kerk-genoodschappen, welke ter bevordering van deugd en goede zeden een Hoogst Wezen eerbiedigen. genieten in deze Volkplanting eene gelylke bescherming der Wetten" (art 1).

De Mist dui met sy formalisties-wettiese of konstitusionele kerkbegrip die afsonderlike kerke (gemeentes) aan die Kaap in die tweede hoofdeel van sy Kerkorde vir die eerste maal in die enkelvoud as "Hervormd Kerkgenootschap" aan. Hoewel die Kaapse kerke (gemeentes) op geen wyse saam georganiseer was nie, vat De Mist se Kerkorde hulle plotseling as eenheid of "Kerkgenootskap" saam. Omdat die genootskap die talrykste en op die platteland die "eenigste" sou wees, verdien dit besondere staatsorg (art 20) en word kerkrade met goedkeuring van die landdros en goewerneur aangestel (vgl Jooste 1946: $102 \mathrm{v}$ ). Die kollegialisme wat die "kerk" as blote vereniging in die staat beskou, "is 'n vergryp aan die wese van die kerk as sodanig" (Klevnhans 1982: 87).

Die owerheid beslis oor die toelating van "kerk-genoodschappen" (art 1) of "byzondere societeiten" (artt 12,13) en mag leerstellings in belang van die "Burgerstaat" wysig of belet (art 5). Die kerkrade moet die goeie sedes en rus van die "Burgerstaat" voorop stel (art 7). Omdat die Kerk vrywillige societeit is, tree die begrip "lidmaatskap" van die kerkstruktuur (art 17) na vore en het in die Afrikaanse kerklike lewe so pospevat dat hierdie formele begrin Calvyn se geestelike norme vir kerkwees grootliks verdring het. Nie meer geloof en instemming met Belydenis nie, maar die formele begrip van "lidmaatskap" aan 'n ding, 'n organisasie. 'n struktuur, 'n genootskap, staan by baie voorop. Die genootskaplike kerkbegrip maak van kerk 'n voorstelling, 'n denk-kategorie, 'n patroon wat as regspersoon binne 'n volk of staat opereer.

4.4 Verskillende opvattings oor kerkvergaderings

Calvyn onderskei drieërlei kerklike mag: om te leer, om te regeer en om wette te maak (Inst IV 8 i). Hy onderskei die gesagstruk. 
tuur vir elke magsfeer. Hy verwerp die Roomse opvatting dat die algemene konsilie van biskoppe beeld van die kerk is $(8 \mathrm{x} ; 9$ i). Die konsilie (sinode) stel leer vas mits die uitspraak die toets van die Skrif kan deurstaan (9 viii). God alleen kan vir sy kerk wette gee. Die kerk het 'n baie beperkte bevoegdheid om wette te maak en mag nie gewetens bind nie, want die kerk is onderworpe aan die wet van vryheid, die Evangelie (9 i, vii). Deur te onderskei tussen "wette en wette", ag Calvyn kerklike bepalings wat "eendrag, orde en vrede" bewaar op sterkte van 1 Kor 14:40 noodsaaklik (10 xxvii). Dit moet egter nuttig en weinig in getal wees (10 xxxii).

Vir regspraak moet daar kerkrade wees om die "geestelike regering" (sleutels, sensuur) te bedien wat radikaal van burgerlike regering onderskei word (11 i). Die kerkraad is 'n "vergadering van ouderlinge" wie se posisie in die kerk met dié van 'n Raad in 'n stad vergelyk kan word maar wie se funksie van totaal ander karakter (bediening van sleutelmag) is.

Kragtens die kerkverband wat die gemeenskaplike geloof (vgl Heid Kat S 21) meebring het Calvyn die weg gewys na konfederale "t'samen-comsten" (Franse KO 1559; DKO 1619 art 29, 30) van "genabuerde Kercken" (art 41 DKO; vgl Emden 1571 art 7-11). Kerke kom in sinode saam om bepaalde agenda (ad hoc) af te handel (art $33 \mathrm{DKO}$ ). Elke samekoms is derhalwe 'n ad hoc geleentheid vir kerkregering en 'n sinode is nie 'n permanente struktuur in eie reg soos 'n parlement wat van tyd tot tyd "in sitting" gaan nie. Die Klassis Amsterdam en die Gekombineerde Vergadering van die verskillende kerke (gemeentes) aan die Kaap (1745-1759) beantwoord nog aan hierdie beskrywing, maar in De Mist se Kerkorde tree die idee van permanente bestuursliggame wat die genootskap demokraties verteenwoordig na vore.

Wanneer die Kerkraad van Kaapstad vra dat De Mist weer die Gekombineerde Kerkvergadering wat in 1759 afgeskaf is, moet instel, skep De Mist 'n struktuur, 'n Algemene Kerkvergadering in eie reg (artt 46-51) wat die Goewerneur moet help om algemene kerksake te bestuur. Die Algemene Kerkvergadering word die bestuur van die genootskap. Du Plooy sê (1982: 374): "Die presbiteriale kerkreg moes vir die kollegialistiese plek maak". By De Mist loer selfs die erastianisme oor die deur omdat die Goewerneur (met of sonder die Algemene Kerkvergadering) die kerk met sy Kerkorde inrig en bestuur. Hoewel De Mist se Kerkorde uit die Rasionalisme opkom, was die "gereformeerde" tradisie van plaaslike kerk-wees ingeslyp en kon nie deur De Mist se Kerkorde meteens uitgewis word nie. Die talle storms in gemeentes gedurende die 19de eeu toon die pvnlike botsing tussen die ou VOC bedeling van selfstandige nlaaslike kerke met die 19de eeuse sentrale kerkbestuur.

Ek meen dat die Rasionalistiese Kerkbegrip waarvan De Mist eksponent is, in die afskeiding van 1834 en Doleansie in Nederland aanwesig was en in Suid-Afrika onder gereformeerdes sy stemnel gedruk het. Die begrip "kerkverband" as 'n oorkoenelende organisasie of struktuur wat in en deur sinodes handel, is daarvan 'n voorbeeld. Die "kerkverband" word gevolglik as struktuur naas die 
"plaaslike kerk" gestel (Vgl H. Bouwman, 1928 I: 137, 484. Nauta 1971: 19, 86, 120, 125. Du Plooy 1982: 2, 82v, 18, 379-381, o a teenoor DCG Fourie 1980, p 303).

\subsection{Die impakt van De Mist se Kerkorde}

Ek meen dat De Mist se staties-kerksentriese institusionele kerkbegrip gedurende die 19de en 20ste eeue in feitlik alle reformatoriese kerke die dag behou het en Calvyn se dinamies-organiese begrip oorwoeker het. Dit is mode om te praat van "our church", "your church", the churches", "council of churches" ens. Elkeen van die gereformeerde Afrikaanse kerkefamilies het 'n taai klap van die kollegialisme weg. Kuyper, toe nog self binne die Nederlandse Hervormde Kerk met sy kollegialistiese Reglement van 1816, het gesê: "Dit Collegiaal systeem is een echt cameleontisch stelsel: ge kunt er elk stelsel mee goedpraten ..." (1883 Tractaat van de Reformatie der Kerken, 52). Calvyn word gekap en verkap om huidige opvattings met Calvyn te versoen. Weinig kerkregtelikes normeer hulle kerkbegrip aan die een algemene (katolieke) kerk van Christus. Inteendeel, die oorkoepeling (imperium) van gemeentes in terme van H. G. Kleyn (1888) se Algemene Kerk en plaatseliike gemeente of "kerkverband" (Kleynhans 1974: 115, 283-285, 297) kom algemeen voor. Hierdie "algemene kerk" is grootliks 'n denkkonstruksie. In talle voorbeelde word hierdie denkkonstruksie aan die universele "onsigbare" kerk van God gelykgestel. Daarvolgens word dan weer soos Rome gedurende die Middeleeue die liggaam van Christus met die eenheid in organisasie vereenselwig. Nauta ken selfs twee soorte gesag aan kerkvergaderinge toe op veronderstelling dat Christus die betrokke struktuur met gesag beklee het (1971: 19, 86, 120, 125). Op dieselfde argument het Rome pouslike gesag gegrond.

\section{CALVYN EN DIE KERKORDELIKE ONTWIKKELING VAN DIE NED GEREF KERK}

\subsection{Die eerste Sinode 1824}

Die eer vir positiewe kerkordelike ontwikkeling gedurende 18241843 kom veral die Skotse predikante toe. In die eerste plek het hulle teenwoordigheid die Goewerneur beweeg om art 46 van De Mist se Kerkorde in werking te stel, sodat 'n eerste Sinode op Kaapse bodem op 2 November in 1824 vergader het. Kleynhans oordeel apologeties gunstig oor die aard van dié sinodale bestuur (Kleynhans 1974: 121, 128, "verstaan en vergewe"; 130 , verskoon die afwyking). Van der Vyver en Van der Linde oordeel egter ongunstig (Ibid $136 \mathrm{v}$ ). Geen invloed van Calvyn word aangedui nie.

\subsection{Die stryd teen Erastianisme}

Die Skotte knoop egter soos Calvyn in Geneve die stryd aan teen die De Mist-Engelse erastianisme met die gevolg dat die Ned Geref Kerk met Ordonnansie 7 van 1843 van praktiese staatsoorheersing bevry word (Kleynhans 1974: 54, 62 v). Formeel oorleef die kopneling met die staat egter. Die Leodolffsaak 1862 laat die een Ned Geref Kerk- (genootskap) uiteenval in landskerke. Gedurende 1907- 
1962 het die onafhanklike NG landskerke as "Gefedereerde Kerke" in 'n Raad saamgewerk (Ibid 148, 352). In 1961 herroep die SA parlement Ordonnansie 7 sodat "kerkvereniging" in 1962 met 'n hersiene KO verwesenlik word (Ibid: $88 \mathrm{v}, 95$ ).

\subsection{Sinode as sentraliserende struktuur}

Die eerste Sinode van 1824 "ter bevordering van de belangen der gezamenlijk Christelijke Hervormde Gemeentes" bring 'n sentraliserende figuur in die kerkregering na vore (Spoelstra 1963: 36). Dit aanvaar (om watter rede ookal as verantwoordelike keuse) dat "de Kerkckenorder door... De Mist ... beschouwd zal moeten worden als de grondwet der Hervormde Kerk in deze volkplanting van dewelke deze latere algemeene bepalingen van Kerkbestier slechts modificatiën en byvoegsels zyn uit veranderde gesteldheid der tyden en omstandighede geboren" (Dreyer 1936: Bouwstowwe 207).

As model vir aanpassing word die berugte" (Hanekom 1951: 50). Algemeen Reglement voor het Bestuur der Hervormde Kerk in het Koninkryk der Nederlanden van 1816 geneem. Die motief waarom sestiende eeuse Kerkordes nie gebruik is nie kan nie aan die staat gewyt word nie. Kritiese insig in die modernistiese en on-Calvynse aard van die erastiaanse kerkwet het ontbreek. Die opset bewys dat geen invloed van Calvyn in dié Kaapse kerkordelike ontwikkeling geïdentifiseer kan word nie. Nie Calvyn nie, maar Nederland is nagevolg. Die volgsaamheid stam waarskynlik uit die koloniale verlede en kan nie deur "special pleading" ongedaan gemak word nic. Daaruit het in NG-kringe spanning ontstaan op kerkregtelike gebied tussen wat hulle wou wees en wat geword het. Weliswaar dokter latere Sinodes ad hoc agv die ongelukkige strvd teen liberale predikante (Kleynhans 1974: 141, vgl Sinode 1873).

Sinode 1897 skrap onder druk van ds. S. J. du Toit elemente van hierargie (Ibid: 142). By hersiening word egter nie indringend na Calvyn as sodanig gevra nie. Met die grootste herstrukturering en nuwe Kerkorde 1962 word die resente Kerkorde van die Gereformeerde Kerk van Nederland olv prof D. Nauta geneem. Daarin het wel reste van die Dordtse Kerkorde van 1619 oorgebly, maar tog onder invloed van baie faktore 'n kerkregtelike grondverskuiwing plaasgevind in die rigting van genootskaplike kerkreg en die Skrifgebondenheid so eie aan Calvyn, het die GKN losgelaat.

Die GKN kerkorde-revisie vervang vanaf 1950 die Dordtse Kerkorde. Dit skep 'n deurlopende sinodestruktuur vir die "kerkverband" naas die plaaslike kerk en kerkraad. Vir Nauta is kerkorde "bepalingen, welke door de in de kerk als bevoegd optredende instantie zijn vastgesteld... om te onderhouden door allen in haar midden, gewone leden zowel als ambtsdragers. Als de bedoelde instantie zal gewoonlijk de synode optreden ... In een kerkorde vinden wij... de algemene wetgeving der kerk" (Nauta 1971: 9). Die kerk gaan dus aan die ampte vooraf. Nauta fundeer die "geaardheid van dit gezag... geheel aangewezen op de vrijwillige erkenning door de leden der gemeente" (Ibid: 123). Die kerk verplaas Christus as hoof van die Kerk. Ons kan hier nie verder op ingaan nie, behalwe om te 
sê dat dit geen invloed van Calvyn nie, maar van die Rasionalisme bewys.

Kleynhans mag van my verskil. Hy toets aan losstaande bepalinge van die Dordtse $\mathrm{KO}$ en oordeel dat die ontwikkeling in die NGKSA "nie in stryd met die gereformeerde beginsels van kerkregering is nie" (Kleynhans 1974: 154). Hy sê oa dat Sinode 1824 die plaaslike kerk as bewuste "grondgedagte in die... presbiteriale stelsel" vasgehou het (Ibid: 125). Die inleiding van die "Kerkorde van die GKSA soos gewysig deur verskillende sinodes" (1980: 12) beweer ook dat die kenmerk van die gereformeerde of presbiteriale stelsel van kerkregering is dat dit nie die kerkgenootskap nie, "maar die plaaslike gemeente (of kerk)" as uitgangspunt neem. Hierdie stelling is hoogs twyfelagtig omdat dit byvoorbeeld (a) reeds 'n kollegium (plaaslik) as basis neem en (b) presbiter(iale) tog nic sinoniem vir eklessia is nie. Die Westminster Confession (art 30, 31) vereenselwig presbiteriale grotendeels met "assemblies" en "presbyteries". Ek betwyfel egter of hierdie kerk- en struktuur-sentriese benadering vir steun op Calvyn kan aanspraak maak. Calvyn gaan van die diens (Ef $4: 11 v$ ) en nie van kerkstruktuur uit nie.

Objektief beskou, stel art 1 van die Reglement van 1824 een enkele "bestuur" vir die oorkoepelende "hervormde kerk" (as kollegium) daar wat "gemeentelijk, ringsgewijze en sinodaal" uitgeoefen word. Daarin is die plaaslike kerk nie "sentrum van die kerklike organisasie" nie, maar die sinodale bestuur gaan ook oor suiwer plaaslike sake. Tog het die gemeentes binne die Nederlandse Hervormde Kerk ten spyte van die Reglement van 1816 sentra van kerklike organisasie gebly, sodat dit nie 'n argument t.o.v. die aard van kerkorde is nie. Ek bly sit met vrae t.o.v. die ontwikkeling in die NGKSA as dit Calvyns moes wees. Waarom het die kommissie 1837-1842 weer die Reglement van 1816 as voorbeeld geneem, terwyl dit die "outonomie van die plaaslike kerk" verloën het (Kleynhans 1974: 132)? Waarom roep B. B. Keet se reformatoriese standpunt in die 20ste eeu so veel spanning en verwarring op (Ibid: 146148)?

Die antwoord is $\mathrm{m} i$ daarin geleë dat die Kaapse Kerk (soos ander Afrikaanse Kerke) nie selfstandig oor die grondbeginsels van Calvyn besin het nie, maar Nederland nagevolg het. Die NGKSA het hom in die vorige eeu deur die Nederl Herv Kerk en in die 20ste deur die Kerkorde van die Geref Kerke van Nederland laat lei (vgl Kleynhans 1974: 149). Net so is die NHK van Afrika deur kerkordelike ontwikkeling in die Nederl Herv Kerk (1950) en die GKSA deur die kerkorderevisie van die GKN 1905 (vgl Sinode 1913) beinvloed.

Ds. S. J. du Toit het die Ned Geref Kerk by die wisseling van die eeu beskuldig dat hulle van die gereformeerde kerkregering afgewyk het (JAS Oberholster 1956: 84v). Die Kerkorde van die NGKSA 1962 verteenwoordig 'n positiewe ontwikkeling t.o.v. dié van 1842, maar regstreeks en bewuste invloed van Calvyn is daarmee nog nie bewys nie. Vandag word al meer besef dat neo-calvinis- 
tiese ontwikkeling in Nederland Calvyn deur die bril van die Rasionalisme lees.

\section{DIE NEDERDUITSCHE HERVORMDE KERK VAN AFRIKA}

In 1858 het die Ned Herv. Kerk in die Suid-Afrikaanse Republiek die wette van die NG Kerk (1842) aangepas en as grondwet vir die staatskerk aanvaar. Die Volksraad het dit in 1863 bekragtig (Lokale Wetten der ZAR, 149 bekendmaking D. v.d. Hoff 28.5.58; EVR 24.10. 63 art 127). Die predikante in die NHK van Afrika het tot die middel van die eeu sterk op Nederland aangeleun. In 1950 toe die Nederlandse Herv. Kerk sy wette hersien het, het die NHK van Afrika gevolg. Prof. A. D. Pont beywer hom om die kerkordelike ontwikkeling nader aan die beginsels van die Reformasie te bring. So omskryf die NHK tans die plaaslike kerk as normale verskyningsvorm van die kerk (A. D. Pont sj).

Prof. Pont kyk krities en met 'n oop gemoed na die kerkordelike onwikkeling en sê dat "in ons kerk enersyds die presbiteriaalsinodale tradisie van die jare 1568-1619 nog lewend is en dit dan veral deur die beginsel-uitsprake van die NGb en die Heid Kat en die Christologie en ekklesiologie wat daarin vervat is. Andersyds word ons kerklike denke bepaal deur die kerkordende denke soos dit in Nederland ontwikkel het ... Daardie kerkordende denke vertoon, terloops, één belangrike tekortkoming en wel in dié sin dat die organiese verband tussen die Christologie en die ekklesiologie losgelaat is en dit dan veral vanweë die verskraalde Christologie van die 19de eeuse verligte toeloë en kerkleiers... Daarby kom dat dit nogal voorkom dat die kerklike orde en kerkordende maatreëls nié gesien word as 'n saak wat in direkte verband met die ekklesiologie en Christologie van die Belydenisskrifte (= amptelike teologie van die kerk) staan nie. Die formele stukke wat dus gebruik word om hierdie vraag te beantwoord kom uit verskillende kerkregtelike en teologiese tradisies en daarom is dit ook so moeilik om presiese formulerings te gee as antwoord op die vraag na die gesan, funksie en handelinge van die meerdere vergaderings. Daarby is dit in ons kerklike lewe nog lank nie uitgemaak of ons byvoorbeeld voorkeur gee aan die Calvinistiese presbiteriaal-sinodale struktuur en of ons die rasionele verligtingsteologie se sinodale struktıur, soos dit tot 1950 gefunksioneer het, verkies nie". (Pont sj: $104 \mathrm{v}$ ).

Hy merk ook tereg sterk invloed van "parlementaristies-demokratiese denke" op (Ibid 118) waaraan m.i. nie een Suid-Afrikaanse kerk ontkom het nie. Talle gereformeerdes beskou "sinode" in dieselfde lig as 'n sekulêre "kerklike parlement".

Pont se opmerking dat "die organiese verband tussen die Christologie en ekklesiologie" gehandhaaf moet word, is behartigingswaardig. Hierdie organiese verband tipeer immers die denke van Calvyn.

\section{DIE KERKORDE VAN DIE GEREF KERK IN SA}

7.1 Ds. D. Postma wou sy "gewysigde" ('n parodie op die Dordtse 
KO van 1619) in die eerste Sinode van 1862 erken kry. Daarin was onmiskenbaar kollegialistiese invloed merkbaar. Die Sinode het egter die Dordtse KO van 1619 aanvaar.

In so ver invloed van Calvyn op die Dordtse KO van 1619 aangewys kan word, het die Sinode 'n Kerkorde aanvaar wat aanspraak op Calvyn kan maak. Die Sinodale Handelinge van die eerste 75 jaar getuig dat daar erns met Calvyn se waarskuwing gemaak is om individue en kerkrade nie met sinodale reglemente en besluite voor te skryf nie. Nadruk is op die vryheid en verantwoordelikheid van die gelowiges en gemeente gelê (vgl B. Spoelstra 1980). Besluite was gerig op die opbou van die plaaslike kerke as geloofsgemeenskappe.

Tog bou geleidelik spanning op. Allerlei voorstelle word terwille van "eenvormigheid" of die kerk as "geheel" gemaak; 'n paralelle sinodestruktuur of "kerkverband" begin naas en selfs oor die plaaslike kerke opereer. Invloed van die Rasionalisme en kollegialisme straal uit benaminge soos "die Gereformeerde Kerk in die OVS" of "Gereformeerde Kerk in Suid-Afrika", "ons kerk", "die hele kerk", sinode Middellande, die Nasionale Sinode as struktuur ens. Verwarring kan gesien word in name waaronder die Kerkorde amptelik uitgegee word. Die "Kerkorde van die Geref Gemeentes in SA" word later in enkelvoud "KO van die GKSA". Daar is spanning tussen 'n gedesentraliseerde en 'n gesentraliseerde kerkbegrip (vgl GPL van der Linde 1978. B. Spoelstra 1981b. : 40v). Die reformatoriese inslag in die Kerkorde mag gerem het maar tog nie verhoed dat selfs 16de eeuse kerkordebeginsels in die 20ste eeuse GKSA deur die bril van Rasionalisme gelees word nie.

7.2 Net soos by die ander twee Afrikaanse Kerke kan makliker Nederlandse as invloed van Calvyn in die kerkordelike ontwikkeling aangedui word. Wanneer die GKN in 1905 die KO hersien, doen die GKSA 1913 dieselfde. Wanneer die GKN in 1950 die Dordtse KO in meer moderne rasionalistiese kategorië herskryf, wou Sinode 1958 in dieselfde spoor volg totdat die Sinode in 1961 besluit om die Dordtse KO te behou. Die Sinode van 1970 wys die nuwe KO van die GKN totaal af en sê dat "'n opmerklike verskuiwing" t.o.v. kerkbegrip, ampsbegrip, gesagsbegrip en ordebegrip in vergelyking met dié van die Dordtse Sinode 1619 daarin plaasgevind het.

7.3 Formeel staan dié Kerkorde van die GKSA die naaste aan die sestiende eeuse Reformasie. Dit mag 'n temperende invloed op die kerklike verskyningsvorm en leefwyse gehad het. Dit lewer egter geen waarborg dat die kerkpraktyk nog in Calvynse gees beoefen word nie.

\section{KERKORDES VANUIT ENGELSE AGTERGROND}

\subsection{Calvym en die Church of England}

Calvyn het op verskillende maniere invloed in Engeland en Skotland uitgeoefen. Hy veroordeel nie die Engelse Kerk oor die episkopaalse kerkregeringsvorm nie. Inteendeel, Calvyn gaan self sterk van die predikante as plaaslike biskopfigure uit (B. Spoelstra 1982: 243-245). Na sy Strassburg-periode maak hy vir herder-ouderlinge 
naas die biskop voorsiening om hierargie te bekamp (Ibid 246249).

Calvyn se biskop bedien egter nie soos die Anglikane en Lutherane 'n landstreek of staat nie, maar is aan 'n bepaalde kerk (gemeente) verbind. Hy reken met meer as een predikant in 'n plaaslike kerk sodat hulle oor mekaar se ampsbediening toesig kan hou. (Vgl Calvyn: Institusie IV, 3 vii; B. Spoelstra 1981a: 12v; R. Boon 1965; J. Plomp 1969; bv. stelling IV; A. van Ginkel 1975: 145v; A. D. Pont 1981, 25 art 20). Tog bly dit 'n onloënbare feit dat Rome, Calvyn, Anglikane en Lutherane die diens van biskop(pe) en nie 'n kerkregtelik omlynde kerkinstituut as vertrekpunt neem nie. In hoever Calvyn invloed op die ontwikkeling van die biskopfiguur in die Anglikaanse kerkregering uitgeoefen het (indien enige), het ek nie nagegaan nie.

\subsection{Calvyn en die Kongregasionaliste en Baptiste}

Die Protestantisme buite die Anglikaanse Kerk is in Engeland gelei deur talle leerlinge van Calvyn, Beza, Bullinger ea. Cartwright veg vir die Presbiteriale kerkinrigting. Die swaar druk en vervolging polariseer hierdie Puriteine as non-konformiste (Baptiste en Kongregasionaliste) t.o.v. die Anglikaanse staatskerk. Hulle kom na 1806 ook na die Kaap en Suid-Afrika.

Die Baptistiese en Kongregasionalistiese reaksie op die Anglikaanse staatskerk in die 17de eeu kan aanspraak maak op invloed van Genéve. Hoewel Robert Browne (1550-1636) deur Nederlandse Anabaptiste beïnvloed is ( $H$. Bouwman 1928: 267), het hy soos gereformeerdes die gemeente as vergadering van gelowiges beklemtoon; nadruk gelê op die hoofskap van Christus oor sy kerk; die Bybel (byna biblisities) as enigste en hoogste gesag in kerkregering geproklameer; die katolieke kerk in die plaaslike organisme van gelowiges gevind; 'n puriteinse (streng Calvinistiese) lewensopvatting en praktyk gehandhaaf.

Runia (1984: 45) beklemtoon dat die Puriteine ook uitwendige hervorming van die kerk verlang het deur vas te hou aan streng Bybelse strukture vir die kerk. Nog meer merkwaardig het D. Deddens (1984: 46-57) verwys na R. Parker, the Cambridge Platform (1648) en die Savoy Declaration (1658) waarin die gees van die Dordtse Kerkorde duidelik te bespeur is. Hulle gaan uit van die "congregational" (plaaslike kerk) kerkvorm, erken gemeenskapsbeoefening tussen die kerke oa. in die saamkom ("meeting") van kerke in "occasional" sinodes. Omdat sinodes nie die gesag van en in die plaaslike kerke kan oorneem nie, kom hulle besluite op "advice" neer.

Volgens Deddens is die tekening van die Independentisme deur skrywer hiervan (L. S. Kruger ea. 1966:27) nie korrek nie (1984: 56). Die Puriteinse kongregasionalisme van Parker het volgens De\}dens Voetius sterk beïnvloed. Tog kry 'n mens in die gereformeerde kerklike lewe die indruk dat die sonde van "Independentisme" baie meer as "kollegialisme" verafsku word. Kyk ons nie dikwels te eensydig teen Browne vas nie? 'n Mens sou seker kon sê dat die kon- 
gregasionalisme van die $17 \mathrm{de}$ eeu meer direkte invloed van Calvyn as die kollegialisme van die 19 de en 20 ste eeue openbaar.

8.3 Calvyn en die Skotse Presbiteriane

John Knox, leerling van Calvyn, is vader van die Skotse Presbiterianisme. Tog wil ek die mening waag dat die Skotte hulle eie weg opgegaan het. Die presbyteries en assemblies word selfs Westminister Confession (art 30,31 ) en verskil van Calvyn se vertrekpunt in die presbiter-biskoppe. Tog het Calvyn op die kerkraad vir tugoefening klem gelê en dit met die Raad van ' $n$ stad vergelyk. Moontlik kan 'n mens sê: Die Puriteine het in reaksie teen die Episkopaalse staatskerk die eerste deel van Institusie Boek IV (hoofstukke 1 tot 3 en $8,12)$ benadruk, terwyl die Presbiteriane weer van Calvyn se kerkrade (IV, hfst 11) uitgegaan het. Calvyn se onderskeiding van drieërlei kerklike magte (om te leer, wette te maak en te regeer. IV/. 8 i) en diffirensiasie tussen dienaars (IV 8 ii, v), konsilies (IV 9 ii, xiii) kerk (IV, 10, i, xxvii, xxxii) en kerkrade (IV 11 i) het die Skotte in die "assembly" saamgetrek.

Dit bly 'n vraag in hoeverre die Skotse nolitieke strukture bvoe. dra het tot hulle meer struktuuragtige en kerksentriese opset. Die onafhanklikheid van die Presbiteriaanse Kerk t.o.v. die staat vertoon invloed van Calvm en Skotse nredikante staan daarvoor in die vuurlinie on die Kaapse Sinode 1837. Die aksent on kerkveroaderinos het aan die Skotse Presbiterianisme alles behalwe "eentrag. orde en vrede" gewaarborg. Inteendeel, aksent on die kerk as struktuur prikkel juis kerklike afskeidings (of bevrydinge).

\section{SLOTSOM}

'n Kritiese stndie toon dat daar geen offisiële Kerkorde aan die Kaan van 1652 tot 1804 gegeld het nie. Die swaartepunt het exter destyds in die kerk-wees van elke gemeente gelê. Uiteraard kan dan geen invloed van Calvyn op 'n Kerkorde nie, maar wel op die gemeentelike patrone aangetoon word.

A. D. Pont sê tereg: "Maar dié kerkorde as orde waarborg nié die regsinnigheid van die kerk of die voortdurende gehoorsaamheid aan Jesus Christus, die Hoof en Heer van die Kerk nie. Daar is geen enkele kerkordende struktuur wat dit waarborg nie" (Pont si: 118). Hy sê ook: "Die relatiewe waarde van die struktuur word hiermee onderstreep solank die geloof en die verkondiging van die kerk volgens die Skrifte is" (aangehaal Spoelstra 1982 b: 56). Kerke kan met gereformeerde Kerkordes hulle as vals openbaar (art $29 \mathrm{NGb}$ ) en die omgekeerde is ook waar: kerke met sekulêre Kerkordes kan erns maak met hulle gehoorsaamheid aan God se Woord en Gees. Nie die formele Kerkorde nie, maar die konkrete geloof en dinamiese gehoorsaamheid aan die Skrif bepaal die karakter van kerk-wees.

Gelewer voor die SA Kerkhistoriese Werkgemeenskap te Stellenbosch 18 Januarie 1984.

\section{BIBLIOGRAFIE}

Bohatec A 1961: Calvins Lehre von Staat und Kirche Breslau. 
Boon R 1965: Apostoljsch ambt en reformatie, Nijkerk.

Bouwman H 1928: Gereformeerde Kerkrecht I. Kampen.

Kerkorden van 1648 en 1658. J. Douma e a. Bezield Verband. Kampen.

Calvyn J Institusie (Red. A. Kuyper 1889. Doesburg).

Deddens D: Synoden bij Robert Parker en in de congregationalistische.

De Wet C J H 1921: Die Kollegiale Kerkreg. Amsterdam.

Dreyer A 1936: Boustowwe vir die Geskiedenis van die Ned Geref Kerke in SA III. Kaapstad.

Du Plooy A le R 1982: Kerkverband. 'n Gereformeerde-kerkregtelike studie. (Ongepubliseerde proefskrif, PU vir $\mathrm{CHO}$ ).

Hanekom T N 1851: Die Liberale Rigting in Suid-Afrika. Stellenbosch.

Jooste JP 1946: Die verhouding tussen kerk en staat aan die Kaap tot die helfte van die 19de eeu. Bloemfontein.

Kleyn H G 1888: Algemene Kerk en plaatselijke gemeente. Dordtrecht.

Kleynhans E P J 1974: Die Kerkregtelike ontwikkeling van die Ned Geref

Kerk in SA 1795-1962 1982: Gereformeerde Kerkreg I. Pretoria.

Kuyper A 1883: Tractaat van de Reformatie der Kerken Amsterdam.

Milner B C 1970: Calvins Doctrine of the Church. Leiden

Nauta D Y971: Verklaring van de Kerkorde van de gereformeerde Kerken in Nederland. Kampen.

Oberholster J A S 1956: Die Geref Kerke onder die Kruis in SA. Kaapstad. Plomp J 1964: De Kerkelijke tucht bij Calvyn. Kampen.

Pont A D 1981: Die Historiese Agtergrond van ons Kerkelike Reg. Pretoria. sj. D'e betekenis van die meerdere vergaderinge tov hulle gesag, funksie en handelinge in die kerk, Herv. Teol. Studies Jrg 38, afl. 2 en 3.

Runiak 1984 Evangel'caly and the Doctrine of the Church... -vangelical. Review of Theology, bl $8 \mathrm{Nr}$. WEF.

Spoelstra B 1963: Die Doppers in SA 1760-1899. Kaapstad.

1975: Persoonlikhede in die vroeë Analioplisme. In die Skriflig Nr. 36. 1980: Die beginsel in art. $30 \mathrm{KO}$, In die Skriflig, $\mathrm{Nr} 55$.

1881 a: Calvyn se kerkreg en invloed op kerke in SA, In die Skriflig. Nr. 59.

1981 b: Die Na-oorlogse kerkregtelike ontwikkeling in die GKSA, In die Skriflig, Nr 57.

1992 a: Calvin's canon law and influence on the Churches in SA. Red B $\mathbf{J}$ vd Walt, Calvinus Reformator.

1982 b: Boekbesprekings. In die Skriflig, Nr. 64.

Spoelstra C 1906: Boustoffen voor de Geschiedenis van de NGKSA, Deel I Amsterdam.

Van der Linde GPL 1965: Die grondbeginsels van die presbiteriale kerkrege ringstelsel. Potchefstroom.

1978: Die beoefening van die kerkreg in die GKSA sedert 1859. In die Skriflig Nr. 48.

Van der Walt $J$ J 1976: Christus as Hoof van die Kerk. Potchefstroom.

Van der Walt 1979: Gemeentes en nagmaal, Gemeentes, Pretoria.

Van Ginkel A 1975: De Ouderling. Amsterdam.

Vorster J D 1956: Die Kerkregtelike ontwikkeling van die Kaapse Kerk onder die Kompanje 1652-1795. Potchefstroom.

Wypkema A 1945: Kultuurgeskiedenis van die Afrikaner I. Kaapstad. 